\title{
The Effect of Pretreated Palm Kernel Shell and Mukah Balingian Coal Co- gasification on Product Yield and Gaseous Composition
}

\author{
Razi Ahmad 1*, Mohd Azlan Mohd Ishak 2,3, Khudzir Ismail 2,3, Nur Nasulhah Kasim², \\ Alina Rahayu Mohamed ${ }^{4}$, Asnida Yanti Ani², Raja Razuan Raja Deris ${ }^{3}$, Khairul Adzfa Radzun ${ }^{3}$ \\ ${ }^{1}$ School of Environmental Engineering, Universiti Malaysia Perlis, 02600 Arau, Perlis, Malaysia \\ ${ }^{2}$ Faculty of Applied Sciences, Universiti Teknologi MARA,Campus Arau, 02600 Arau, Perlis, Malaysia \\ ${ }^{3}$ Coal and Biomass Energy Research Group, Universiti Teknologi MARA, 40450 Shah Alam, Selangor, Malaysia \\ ${ }^{4}$ Department of Chemical Engineering Technology, Faculty of Engineering Technology, Universiti Malaysia \\ Perlis, 02100 Padang Besar, Perlis, Malaysia
}

\begin{abstract}
In this study, co-gasification of palm kernel shell (PKS) and low-rank Malaysian coal (MB) was carried out in a fixed bed reactor. For the pretreated samples, PKS was torrefied at $270^{\circ} \mathrm{C}$ $\left(\mathrm{PKS}_{\mathrm{To}}\right)$ and $\mathrm{MB}$ was preheated at $250^{\circ} \mathrm{C}\left(\mathrm{MB}_{\mathrm{Pr}}\right)$ for $1 \mathrm{~h}$, respectively, prior to co-gasification at $767^{\circ} \mathrm{C}$, with a biomass blending ratio of $52 \%$ and a steam flow rate of $55 \mathrm{~mL} / \mathrm{min}$. The effect of different blending combinations was investigated towards product yields, namely gas, tar, char and gases composition. The co-gasification on both pretreated $\left(\mathrm{PKS}_{\mathrm{T}_{\mathrm{o}}} / \mathrm{MB}_{\mathrm{Pr}}\right)$ and catalyst-pretreated (Cat$\mathrm{PKS}_{\mathrm{To}} / \mathrm{MB}_{\mathrm{Pr}}$ ) produced a greater gas yield, with lesser tar and char yield than both untreated PKS and $\mathrm{MB}\left(\mathrm{PKS}_{\mathrm{Un}} / \mathrm{MB}_{\mathrm{Un}}\right)$ and pretreated PKS and untreated $\mathrm{MB}\left(\mathrm{PKS}_{\mathrm{To}} / \mathrm{MB}_{\mathrm{Un}}\right)$. The $\mathrm{PKS}_{\mathrm{To}} / \mathrm{MB} \operatorname{Pr}$ was found to enhance the $\mathrm{H}_{2}$ production by $63.9 \%$ and $41 \%$ than $\mathrm{PKS}_{\mathrm{Un}} / \mathrm{MB}_{\mathrm{Un}}$ and $\mathrm{PKS}_{\mathrm{To}} / \mathrm{MB}_{\mathrm{Un}}$, respectively, at $45 \mathrm{~min}$ of reaction time. Thus, the pretreatment on both samples had a significant impact on the distribution and composition of product yields during co-gasification. As a conclusion, the pretreated sample, which has been upgraded on characteristics such as higher carbon and lower oxygen content than the untreated sample was revealed to enhance gas yield and $\mathrm{H}_{2}$ production during co-gasification.
\end{abstract}

Keywords: Biomass; Gasification; Low rank coal; Palm kernel shell; Pretreatment

\section{Introduction}

Currently, the application of the world energy, which releases carbon dioxide, sulfur oxide and nitrogen oxide, has become an issue (Taba et al., 2012). The other problems are associated with the usage of fossil fuels and production of greenhouse gas. Thus, gasification, which is established as an energy-efficient technology, has an acknowledged important consideration (Sulaiman et al., 2012; Heidenreich and Foscolo, 2015). Presently, coal is the main feedstock in gasification and is expected to be applied as the energy resource for many decades ahead. However, this direction is difficult to achieve due to the increase in energy demand, which has caused the shortage of supply and the reduction of high-rank coal (Mohr et al., 2015). Consequently, one of the approaches is to utilize the abundant low-rank coal and biomass in gasification.

The low-rank coal is almost partial towards the world's entire coal deposits compared to the high-rank coal. The usage of low-rank coal in thermal conversion is economical due 
to its low pricing. However, low-rank coal as a substitute for high-rank coal has several limitations, such as low calorific value and high moisture and oxygen content (Rao et al., 2015). These drawbacks can be minimized by using the pretreated or upgraded low-rank coal in gasification (Xia et al., 2015). Similarly, the utilization of biomass, which is a renewable and environmentally friendly resource during gasification, created several problems. Untreated biomass has relatively low energy, high moisture and oxygenated compound, hygroscopic behavior and poor grindability (Chen et al., 2015). Accordingly, the pretreated biomass improved in energy density; hygroscopic characteristics and grindability overcome the disadvantage of untreated biomass and are suitable for further thermochemical conversion (Nhuchhen et al., 2014; Yuliansyah et al., 2019).

Biomass commonly has higher hydrogen content than coal and it is appropriate to mix both together. Further, the alkali and alkaline earth metals (AAEM) in biomass catalyze the gasification of char resulting from coal pyrolysis. Equally, the high silica $\left(\mathrm{SiO}_{2}\right)$ content in coal acts as an effective catalyst for tar cracking to light hydrocarbon in thermal conversion (Mallick et al., 2017). However, the gasification of biomass indicated more drawback than coal gasification, where biomass has high oxygenated compound and moisture content and low energy density (Ahmad et al., 2014; Kasim et al., 2019; Ahmad et al., 2019). Thus, cogasification of biomass and coal can be substituted for individual gasification, as it may improve their disadvantages on both feedstocks (Brar et al., 2012).

Co-gasification has been studied by some researchers. It improved the overall gas and hydrogen composition more than individual gasification (Howaniec and Smoliński, 2013) and showed the synergistic influence in terms of high gas yield, low tar and char yield at 1:1 biomass-coal ratio (Krerkkaiwan et al., 2013). There were synergistic effects in the decrease of char yield and increase of gas yield in the co-conversion of coal-biomass blending (Yuan et al., 2012). Consequently, the synergy between biomass and coal cogasification increases the gas yield, gasification efficiency and reactivity of char and reduces the tar yield (Winaya et al., 2015). Upgraded biomass, such as torrefied pellets, was suitable to obtain low tar yield (Dudyński et al., 2015), and torrefied bamboo was also established to produce high syngas yields (Kuo et al., 2014). Moreover, the blending of pretreated biomass and sub-bituminous coal in co-gasification was found to minimize the formation of agglomerates in fluidized bed reactors (Strege et al., 2011). Definitely, torrefaction creates the gasification behavior of the biomass in its approach to coal where the $\mathrm{H}_{2}$ composition in the syngas of torrefied biomass is comparable with coal.

Furthermore, one of the most efficient techniques of producing higher gas qualities is steam gasification. It offers the highest composition of hydrogen (Parthasarathy and Narayanan, 2014). Numerous studies have reported enhanced syngas yield and carbon conversion efficiency when steam was utilized as a gasifying agent (Howaniec et al., 2011; Moghadam et al., 2014; Naqvi et., 2016).

Consequently, the enhancement in pretreated material characteristics improved the gasification performance and hydrogen production (Chen et al., 2013). Thus, the cogasification of pretreated PKS and MB coal is categorically novel in this area. The main objective of this research was to explore the influence of pretreated PKS and MB on cogasification. The influence on co-gasification was discovered in terms of product yields, namely char, tar, gas and gases composition.

\section{Methods}

\subsection{Materials}

PKS as a biomass sample was supplied from an oil palm mill located in Penang, Malaysia. MB, which is categorized as low-rank sub-bituminous coal from Sarawak, 
Malaysia, was used as the coal sample. Both samples were ground and separated through a finer screen to get particle sizes in the range of $200 \mu \mathrm{m}$ to $400 \mu \mathrm{m}$. The untreated PKS $\left(\mathrm{PKS}_{\mathrm{Un}}\right)$ and untreated $\mathrm{MB}\left(\mathrm{MB}_{\mathrm{Un}}\right)$ were dried in at a temperature of $105^{\circ} \mathrm{C}$ for 24 hours and stored in an air-tight container for further analyses and pretreatment.

The pretreated or torrefied PKS $\left(\mathrm{PKS}_{\mathrm{To}}\right)$ was produced via torrefaction at a temperature of $270^{\circ} \mathrm{C}$ with a holding time of $1 \mathrm{~h}$, and the preheated $\mathrm{MB}(\mathrm{MB} \operatorname{Pr})$ was produced via preheating at a temperature of $250^{\circ} \mathrm{C}$ with a holding time of $1 \mathrm{~h}$ using fixed bed reactor. Both $\mathrm{PKS}_{\mathrm{To}}$ and $\mathrm{MB}_{\mathrm{Pr}}$ were prepared and selected according to our previous work (Ahmad et al., 2019). The $\mathrm{PKS}_{\mathrm{To}}$ and $\mathrm{MB}$ Pr presented an enhancement on fuel properties in terms of high calorific value, energy density, carbon content with low moisture and oxygen content at selected pretreatment temperatures (Ahmad et al., 2019). The proximate and ultimate analyses were carried out using Mettler Toledo TGA/DSC thermogravimetric analyzer and Leco CHNS-932 elemental analyzer, respectively. The calorific value was determined by using Leco AC-350 bomb calorimeter. The characteristics of all samples are shown in Table 1 . The dolomite was used as the catalyst during catalytic co-gasification. The dolomite was sieved to obtain a fraction with a particle size of $45 \mu \mathrm{m}$. It was calcined at a temperature of $900^{\circ} \mathrm{C}$ for $5 \mathrm{~h}$.

Table 1 Characteristics of PKS and MB

\begin{tabular}{lcccc}
\hline \multicolumn{1}{c}{ Analysis } & $\mathrm{PKS}_{\mathrm{Un}}$ & $\mathrm{PKS}_{\mathrm{To}}$ & $\mathrm{MB}_{\mathrm{Un}}$ & $\mathrm{MB}_{\mathrm{Pr}}$ \\
\hline Proximate analysis (wt.\%) & & & & \\
Moisture & 10.60 & 1.58 & 21.50 & 4.78 \\
Volatile matter & 77.54 & 46.99 & 38.00 & 24.57 \\
Fixed carbon & 10.95 & 49.13 & 35.60 & 64.17 \\
Ash & 0.91 & 2.30 & 4.90 & 6.48 \\
Ultimate analysis (wt.\%) & & & & \\
Carbon & 47.67 & 52.34 & 54.52 & 59.50 \\
Hydrogen & 5.52 & 3.98 & 4.75 & 4.16 \\
Nitrogen & 0.39 & 0.90 & 0.97 & 1.00 \\
Sulphur & 0 & 0 & 0 & 0 \\
Oxygen (calculated by & 46.42 & 42.78 & 39.76 & 35.34 \\
difference) & 18.20 & 20.90 & 20.10 & 23.80 \\
Calorific value (MJ/kg) & & & & \\
\hline
\end{tabular}

\subsection{Co-gasification}

The co-gasification experiments were carried out using a fixed bed reactor with an internal diameter of $6 \mathrm{~cm}$ and a height of $30 \mathrm{~cm}$ at atmospheric pressure. The reactor was heated using an electric furnace. Figure 1 shows the schematic diagram of co-gasification experimental setup. Four different blending samples were used during co-gasification: (i) untreated $\mathrm{PKS} / \mathrm{MB}\left(\mathrm{PKS}_{\mathrm{Un}} / \mathrm{MB}_{\mathrm{Un}}\right)$, (ii) torrefied PKS/untreated $\mathrm{MB}\left(\mathrm{PKS}_{\mathrm{To}} / \mathrm{MB}_{\mathrm{Un}}\right)$, (iii) torrefied $\mathrm{PKS} /$ preheated $\mathrm{MB}\left(\mathrm{PKS}_{\mathrm{To}} / \mathrm{MB}_{\mathrm{Pr}}\right)$, and (iv) catalyst-torrefied $\mathrm{PKS} /$ preheated $\mathrm{MB}$ (Cat-PKS $\mathrm{To}_{\mathrm{T}} / \mathrm{MB}_{\mathrm{Pr}}$ ).

About $5 \mathrm{~g}$ of sample was placed inside the reactor. Initially, the reactor was purged with a nitrogen flow rate of $500 \mathrm{~mL} / \mathrm{min}$ for $10 \mathrm{~min}$. Then, the sample was heated to the desired gasification temperature with a heating rate of $50^{\circ} \mathrm{C} / \mathrm{min}$. A nitrogen flow was continued to generate an inert atmosphere inside the reactor. After the reactor reached the desired cogasification temperature, the steam that was produced from the steam generator flowed into the reactor, and the nitrogen flow was stopped. The steam temperature was $120^{\circ} \mathrm{C}$ at a pressure of 2 bar. The steam co-gasification was held for $60 \mathrm{~min}$. The co-gasification was 
carried out using optimization condition at a gasification temperature of $767^{\circ} \mathrm{C}$, biomass blending ratio of $52 \%$ and steam flow rate of $55 \mathrm{~mL} / \mathrm{min}$ based on our previous studies (Ahmad et al., 2018). These optimized conditions were used as resulting in maximum gas yield, minimum char and tar yield during the co-gasification of $\mathrm{PKS}_{\mathrm{To}} / \mathrm{MB}_{\mathrm{Pr}}$. In catalytic cogasification, $10 \%$ of calcined dolomite was mixed with the $\mathrm{PKS}_{\mathrm{To}} / \mathrm{MB}_{\mathrm{Pr}}$.

The volatile product that left the reactor from the upper side was condensed in a tar trap. The tar trap consisted of two bottles placed in the ice bath. The non-condensable gases passed through cotton wool and silica gel to remove the remaining moisture. Then, the gas was collected in a gas bag every $15 \mathrm{~min}$ from the starting of steam co-gasification. When the process was completed, the furnace was switched off and the reactor was left to cool to the ambient temperature. The char product was weighted once it reached room temperature. The tar product was also measured. The gas yield was calculated by difference based on the total mass balances considering the tar and char yields. The gas analysis was carried out using Agilent 6890N and gas chromatography with a thermal conductivity detector (GCTCD). The produced gases, namely $\mathrm{H}_{2}, \mathrm{CO}, \mathrm{CO}_{2}$ and $\mathrm{CH}_{4}$, were quantitatively analyzed using purified Ar as the carrier gas.
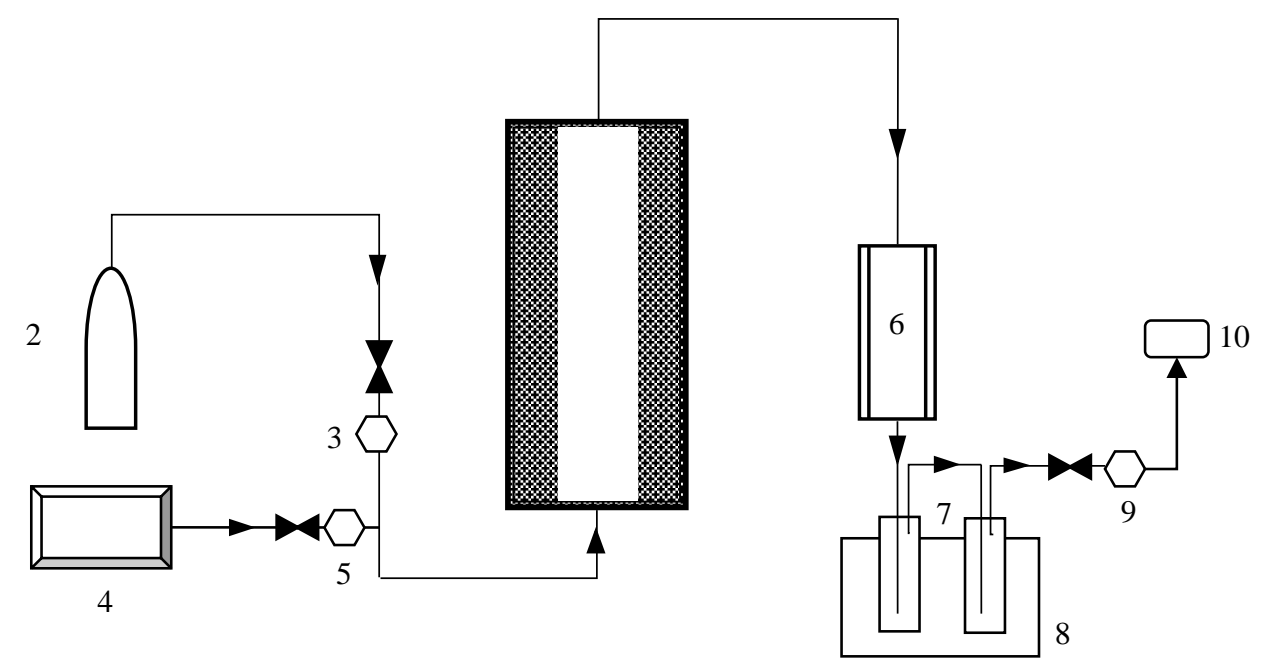

Figure 1 Schematic diagram of co-gasification experimental setup: (1) Fix-bed reactor, (2) $\mathrm{N}_{2}$ tank, (3) $\mathrm{N}_{2}$ flow meter, (4) Steam generator, (5) Steam flow meter, (6) Condenser, (7) Tar trap, (8) Ice bath, (9) Outlet gas flow meter, (10) Gas bag

The reaction mechanisms, such as pyrolysis reaction (Equation 1), tar cracking and reforming reaction (Equation 2), water-gas reaction (Equation 3), water-gas shift reaction (Equation 4), methanation reaction (Equation 5), steam reforming reaction (Equation 6), and Boudouard reaction (Equation 7), were involved during co-gasification.

$$
\begin{gathered}
\text { Biomass (s) }+ \text { Coal (s) } \rightarrow \mathrm{C}_{\text {biomass }+ \text { coal }(\mathrm{s})}+\mathrm{Tar}(\mathrm{l})+\text { Gases } \\
\operatorname{Tar}(\mathrm{l})+\mathrm{H}_{2} \mathrm{O}(\mathrm{g}) \rightarrow \text { Gases }\left(\mathrm{H}_{2}, \mathrm{CO}, \mathrm{CO}_{2}, \mathrm{CH}_{4}, \mathrm{C}_{\mathrm{n}} \mathrm{H}_{\mathrm{m}}\right) \\
\mathrm{C}(\mathrm{s})+\mathrm{H}_{2} \mathrm{O}(\mathrm{g}) \rightarrow \mathrm{CO}(\mathrm{g})+\mathrm{H}_{2}(\mathrm{~g}) \\
\mathrm{CO}(\mathrm{g})+\mathrm{H}_{2} \mathrm{O}(\mathrm{g}) \rightarrow \mathrm{CO}_{2}(\mathrm{~g})+\mathrm{H}_{2}(\mathrm{~g}) \\
\mathrm{C} \mathrm{( \textrm {s } )}+2 \mathrm{H}_{2}(\mathrm{~g}) \rightarrow \mathrm{CH}_{4}(\mathrm{~g}) \\
\mathrm{CH}_{4(\mathrm{~g})}+\mathrm{H}_{2} \mathrm{O}(\mathrm{g}) \rightarrow \mathrm{CO}(\mathrm{g})+3 \mathrm{H}_{2}(\mathrm{~g}) \\
\mathrm{C}(\mathrm{s})+\mathrm{CO}_{2(\mathrm{~g})} \rightarrow 2 \mathrm{CO}(\mathrm{g})
\end{gathered}
$$




\section{Results and Discussion}

\subsection{Effect of Co-gasification on Product Yield}

Figure 2 presents the results obtained in terms of product yield, namely char, tar and gas. The co-gasification of $\mathrm{PKS}_{\mathrm{To}} / \mathrm{MB}_{\mathrm{Pr}}$ and Cat- $\mathrm{PKS}_{\mathrm{To}} / \mathrm{MB}_{\mathrm{Pr}}$ produced higher gas yield than co-gasification of $\mathrm{PKS}_{\mathrm{Un}} / \mathrm{MB}_{\mathrm{Un}}$ and $\mathrm{PKS} \mathrm{To}_{\mathrm{To}} / \mathrm{MB}_{\mathrm{Un}}$. The gas yield increased by about $32.2 \%$ and 33.3\% using $\mathrm{PKS}_{\mathrm{To}} / \mathrm{MB}_{\mathrm{Pr}}$ and Cat- $\mathrm{PKS}_{\mathrm{To}} / \mathrm{MB}_{\mathrm{Pr}}$ samples, respectively, more than using the $\mathrm{PKS}_{\mathrm{Un}} / \mathrm{MB}_{\mathrm{Un}}$ sample. The pretreated sample exhibited a notable impact on gas production to produce higher gas yield than the untreated sample. The Cat- $\mathrm{PKS}_{\mathrm{To}} / \mathrm{MB}_{\mathrm{Pr}}$ displays a minor increase in gas yield where only $1.1 \%$ is different from $\mathrm{PKS}_{\mathrm{To}} / \mathrm{MB}_{\mathrm{Pr}}$ sample. Gas production using both pretreated samples was higher than Berrueco et al. (2014), which increased by only $7 \%$ more than the untreated sample on gasification of pretreated Norwegian forest residue. Moreover, the gasification of pretreated Norwegian forest residues with dolomite catalyst also showed little increase of $2 \%$ on gas yield (Berrueco et al., 2014).

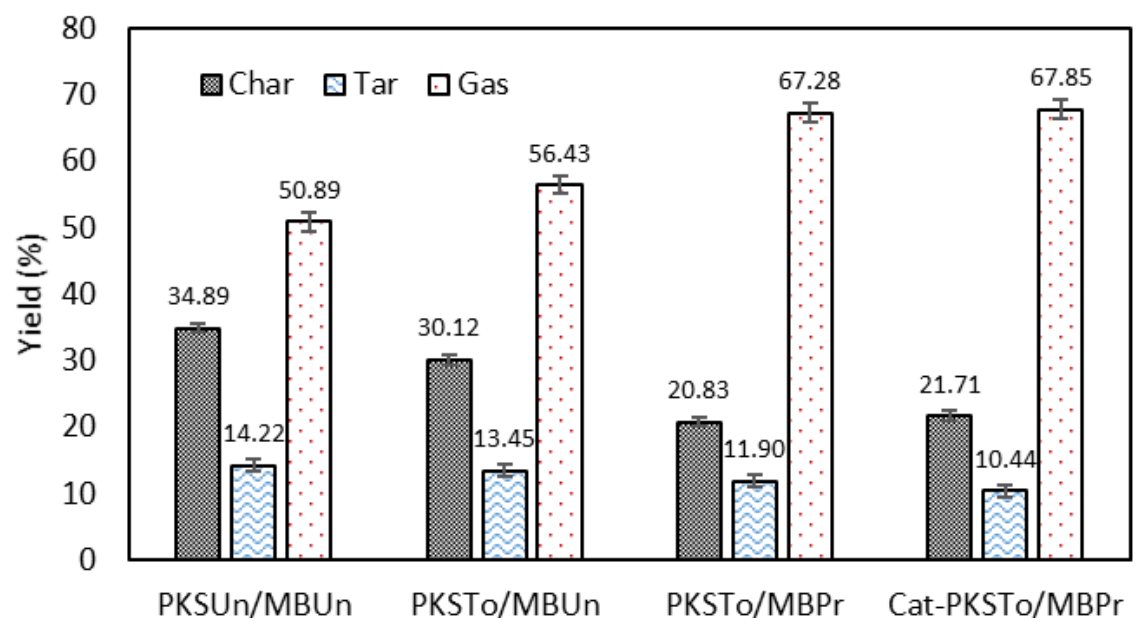

Figure 2 Effect of co-gasification of $\mathrm{PKS}_{\mathrm{Un}} / \mathrm{MB}_{\mathrm{Un}}, \mathrm{PKS}_{\mathrm{To}} / \mathrm{MB}_{\mathrm{Un}}, \mathrm{PKS}_{\mathrm{To}} / \mathrm{MB}_{\mathrm{Pr}}$, and Cat-PKS $\mathrm{P}_{\mathrm{To}} / \mathrm{MB}_{\mathrm{Pr}}$ on product yield

The tar yield reduced from $14.2 \%$ to $11.9 \%$ and $14.2 \%$ to $10.4 \%$ for $\mathrm{PKS}_{\mathrm{To}} / \mathrm{MB}_{\mathrm{Pr}}$ and Cat- $\mathrm{PKS}_{\mathrm{To}} / \mathrm{MB}_{\mathrm{Pr}}$ samples, respectively, which is more than for $\mathrm{PKS}_{\mathrm{Un}} / \mathrm{MB}_{\mathrm{Un}}$. The Cat$\mathrm{PKS}_{\mathrm{To}} / \mathrm{MB}_{\mathrm{Pr}}$ sample further reduced by $1.5 \%$ more than the $\mathrm{PKS}_{\mathrm{To}} / \mathrm{MB}_{\mathrm{Pr}}$ sample for tar yield. Low tar yield is necessary for co-gasification. Thus, using both pretreated samples had noticeably reduced the tar yield in co-gasification as a significance of the partial removal of the oxygenated components of biomass and low-rank coal and volatiles through the pretreatment process. Moreover, the addition of a catalyst to both pretreated samples promotes tar reduction. These results confirm the catalytic effect of calcined dolomite that converted the tar in-situ and therefore reduced the tar yield (Berrueco et al., 2014). However, the decreasing of tar yield was not extensive when the catalyst was used together with the pretreated sample. This fact showed that in this study, using only $\mathrm{PKS}_{\mathrm{To}} / \mathrm{MB}_{\mathrm{Pr}}$ was enough to reduce the tar.

The char yield decreased about $40.3 \%$ and $37.8 \%$ for $\mathrm{PKS}_{\mathrm{To}} / \mathrm{MB}_{\mathrm{Pr}}$ and Cat- $\mathrm{PKS}_{\mathrm{To}} / \mathrm{MB}_{\mathrm{Pr}}$, respectively, which is more than for the $\mathrm{PKS}_{U n} / \mathrm{MB}_{U n}$ sample. The low char yield for $\mathrm{PKS}_{\mathrm{To}} / \mathrm{MB}_{\mathrm{Pr}}$ and Cat- $\mathrm{PKS}_{\mathrm{To}} / \mathrm{MB}_{\mathrm{Pr}}$ samples was associated with the increase of conversion to gas product using pretreated feedstock. Moreover, this occurrence, which was affected by the low moisture and oxygenated compound of pretreated feedstock, as presented in Table 1 , made it comforting to be used as a solid fuel through co-gasification. The use of Cat$\mathrm{PKS}_{\mathrm{To}} / \mathrm{MB}_{\mathrm{Pr}}$ sample did not show any significant difference from the use of the $\mathrm{PKS}_{\mathrm{To}} / \mathrm{MB}_{\mathrm{Pr}}$ 
sample.

Therefore, the issue of the disadvantages characteristic of untreated biomass and lowrank coal, such as low carbon and high moisture and oxygenated content, had been overcome through the pretreatment process, which resulted in the improvement of gasification products. Additionally, this revealed that using both pretreated samples without the catalyst had extensively improved the co-gasification product yield with increasing gas yield while decreasing tar and char yield. However, the effect of the catalyst on the product yield can be seen by the optimization of co-gasification parameter, which comprises the catalyst factor.

\subsection{Effect of Co-gasification on Gases Composition}

Figure 3 shows the effect of co-gasification of $\mathrm{PKS}_{U n} / \mathrm{MB}_{U n}, \mathrm{PKS}_{\mathrm{To}} / \mathrm{MB}_{U n}, \mathrm{PKS}_{\mathrm{To}} / \mathrm{MB}_{\mathrm{Pr}}$, and Cat-PKS $\mathrm{To}_{\mathrm{o}} / \mathrm{MB}_{\mathrm{Pr}}$ on gases composition at various reaction times. In Figure $3 \mathrm{a}$, the $\mathrm{H}_{2}$ composition increased with increasing reaction time for all samples. The $\mathrm{PKS}_{\mathrm{To}} / \mathrm{MB}_{\mathrm{Pr}}$ and Cat- $\mathrm{PKS}_{\mathrm{To}} / \mathrm{MB}_{\mathrm{Pr}}$ samples enhanced the $\mathrm{H}_{2}$ production by about $63.9 \%$ and $70.7 \%$, respectively, more than $\mathrm{PKS}_{U n} / \mathrm{MB}_{\text {Un }}$ sample at 45 min reaction time. Also, the $\mathrm{PKS}_{\mathrm{To}} / \mathrm{MB}_{\mathrm{Pr}}$ and Cat- $\mathrm{PKS}_{\mathrm{To}} / \mathrm{MB}_{\mathrm{Pr}}$ increased the $\mathrm{H}_{2}$ production by about $41 \%$ and $46.8 \%$, respectively, more than $\mathrm{PKS}_{\mathrm{To}} / \mathrm{MB}_{\text {Un }}$ sample at 45 min reaction time.

The pretreatment of biomass and low-rank coal increased carbon and calorific value, as shown in Table 1. Therefore, these had increased the energy density of the pretreated sample. As a result, more carbon had the potential to react with steam through water-gas and water-gas shift reaction during co-gasification. High production of $\mathrm{H}_{2}$ is in accordance with the high quantity of carbon content in pretreated samples compared with the carbon content in $\mathrm{PKS}_{\mathrm{Un}} / \mathrm{MB}_{\mathrm{Un}}$ and $\mathrm{PKS}_{\mathrm{To}} / \mathrm{MB}_{U n}$ samples. $\mathrm{H}_{2}$ is mostly generated from the reaction of carbon with steam in the co-gasification reactor. This fact provides a great opportunity for the utilization of pretreated biomass and low-rank coal for the enrichment of $\mathrm{H}_{2}$ production. In the case of Cat- $\mathrm{PKS}_{\mathrm{To}} / \mathrm{MB}_{\mathrm{Pr}}$, the addition of calcined dolomite catalyst showed a slightly higher increment than $\mathrm{PKS}_{\mathrm{To}} / \mathrm{MB}_{\mathrm{Pr}}$ on $\mathrm{H}_{2}$ production at longer reaction times of 45 and 60 min.

The production of $\mathrm{CO}$ decreased with increasing reaction time, as illustrated in Figure $3 \mathrm{~b}$. The $\mathrm{PKS}_{\mathrm{Un}} / \mathrm{MB}_{\mathrm{Un}}$ blending produced a higher amount of $\mathrm{CO}$ than $\mathrm{PKS}_{\mathrm{To}} / \mathrm{MB}_{\mathrm{Pr}}$ and Cat$\mathrm{PKS}_{\mathrm{To}} / \mathrm{MB}_{\mathrm{Pr}}$ blending. At 45 min reaction time, CO decreased to 46.3\%, 42.5\%, 32.7\% and $22.7 \%$ for $\mathrm{PKS}_{U n} / \mathrm{MB}_{U n}, \mathrm{PKS}_{\mathrm{To}} / \mathrm{MB}_{U n}, \mathrm{PKS}_{\mathrm{To}} / \mathrm{MB}_{\mathrm{Pr}}$ and Cat-PKS $\mathrm{To}_{\mathrm{To}} / \mathrm{MB}_{\mathrm{Pr}}$ blendings, correspondingly. Figure 3c showed that the $\mathrm{CO}_{2}$ content decreased as the reaction time increased. However, the Cat- $\mathrm{PKS}_{\mathrm{To}} / \mathrm{MB}_{\mathrm{Pr}}$ sample showed a dissimilar trend for $\mathrm{CO}_{2}$ content than other blendings. For example, the $\mathrm{CO}_{2}$ content using Cat-PKS $\mathrm{T}_{\mathrm{To}} / \mathrm{MB}_{\mathrm{Pr}}$ blending was higher than the untreated and pretreated sample at $15 \mathrm{~min}$. Then, at $30 \mathrm{~min}$, the $\mathrm{CO}_{2}$ content was lower than $\mathrm{PKS}_{\mathrm{Un}} / \mathrm{MB}_{\mathrm{Un}}$ and $\mathrm{PKS}_{\mathrm{To}} / \mathrm{MB}_{\mathrm{Pr}}$ blending, while at longer reaction times of 45 and $60 \mathrm{~min}$, the Cat-PKS $\mathrm{To}_{\mathrm{To}} / \mathrm{MB}_{\mathrm{Pr}}$ produced the highest $\mathrm{CO}_{2}$ content. The $\mathrm{PKS}_{\mathrm{To}} / \mathrm{MB}_{\mathrm{Pr}}$ showed a significant reduction of $\mathrm{CO}_{2}$ at 45 and 60 min reaction times. Figure $3 \mathrm{~d}$ showed that the $\mathrm{CH}_{4}$ composition increased with increasing reaction time. The $\mathrm{PKS}_{\mathrm{To}} / \mathrm{MB}_{\mathrm{Pr}}$ and Cat$\mathrm{PKS}_{\mathrm{To}} / \mathrm{MB}_{\mathrm{Pr}}$ produced more $\mathrm{CH}_{4}$ than $\mathrm{PKS}_{\mathrm{Un}} / \mathrm{MB}_{\text {Un }}$ and $\mathrm{PKS}_{\mathrm{To}} / \mathrm{MB}_{\text {Un }}$ blending. The Cat$\mathrm{PKS}_{\mathrm{To}} / \mathrm{MBPr}_{\mathrm{Pr}}$ showed the highest $\mathrm{CH}_{4}$ production of $22.9 \%$ at 30 min reaction time, while at 45 and 60 min reaction times the $\mathrm{PKS}_{\mathrm{To}} / \mathrm{MB}_{\operatorname{Pr}}$ produced higher $\mathrm{CH}_{4}$ than $\mathrm{PKS}_{U n} / \mathrm{MB}_{U n}$, $\mathrm{PKS}_{\mathrm{To}} / \mathrm{MB}_{\mathrm{Un}}$ and Cat-PKS $\mathrm{To}_{\mathrm{T}} / \mathrm{MB}_{\mathrm{Pr}}$. $\mathrm{CH}_{4}$ in $\mathrm{PKS}_{\mathrm{To}} / \mathrm{MB}_{\operatorname{Pr}}$ was produced twice more than $\mathrm{PKS}_{U n} / \mathrm{MB}_{\text {Un }}$ at 45 min reaction time.

The production of gases in co-gasification involves several chemical reactions. The primary devolatisation, which is pyrolysis reaction (Equation 1) and tar cracking and reforming reaction (Equation 2), were involved in the early stage of co-gasification (Valdés et al., 2016). At 15 min reaction time, higher CO composition was produced than other gases 
$\left(\mathrm{H}_{2}, \mathrm{CO}_{2}\right.$ and $\left.\mathrm{CH}_{4}\right)$ for $\mathrm{PKS}_{U n} / \mathrm{MB}_{U n}, \mathrm{PKS}_{\mathrm{To}} / \mathrm{MB}_{U n}$, and $\mathrm{PKS}_{\mathrm{To}} / \mathrm{MB}_{\mathrm{Pr}}$. These indicated that the reaction, which favors the production of $\mathrm{CO}$, was greater with steam gasification at $15 \mathrm{~min}$. At these stages, the chemical reactions involved were preferred on water-gas reaction (Equation 3). The water-gas reaction is a reaction of carbon by steam, which can be derived from solid fuel. Cat- $\mathrm{PKS}_{\mathrm{To}} / \mathrm{MB}_{\mathrm{Pr}}$ produced the highest $\mathrm{CO}_{2}$ composition, where the watergas shift reaction (Equation 4) was dominant at $15 \mathrm{~min}$. The water gas-shift results in an increase in the ratio of $\mathrm{CO}_{2}$ to $\mathrm{CO}$ and of $\mathrm{H}_{2}$ to $\mathrm{CO}$.

At 30 and $45 \mathrm{~min}, \mathrm{H}_{2}$ and $\mathrm{CH}_{4}$ compositions showed increment for all samples. These were directed from the water-gas reaction (Equation 3), methanation reaction (Equation 5 ) and steam reforming reaction (Equation 6). The highest $\mathrm{CO}$ composition was produced for $\mathrm{PKS}_{U n} / \mathrm{MB}_{U n}$, blending at 30 and $45 \mathrm{~min}$ due to the prominence of the Boudouard reaction (Equation 7 ) at this time. Bourdourd reaction is the reaction of the char with $\mathrm{CO}_{2}$ during gasification. However, at longer reaction times of 45 and $60 \mathrm{~min}$, the production of $\mathrm{H}_{2}$ and $\mathrm{CO}$ become dominant for $\mathrm{PKS}_{\mathrm{To}} / \mathrm{MB}_{\mathrm{Pr}}$ due to water-gas reaction, steam reforming reaction and Boudouard reaction. For Cat- $\mathrm{PKS}_{\mathrm{To}} / \mathrm{MB}_{\mathrm{Pr}}$, the $\mathrm{H}_{2}$ and $\mathrm{CO}_{2}$ production were favored due to the steam-reforming reaction and water-gas shift reaction.

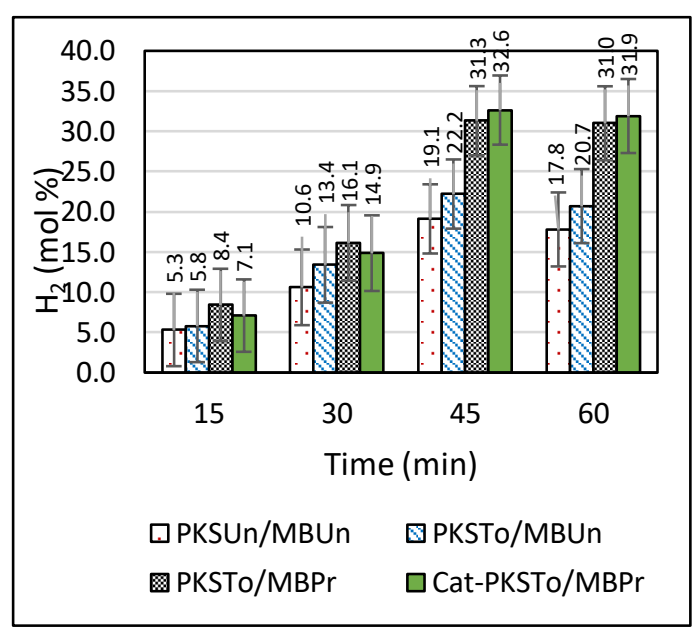

(a) $\mathrm{H}_{2}$

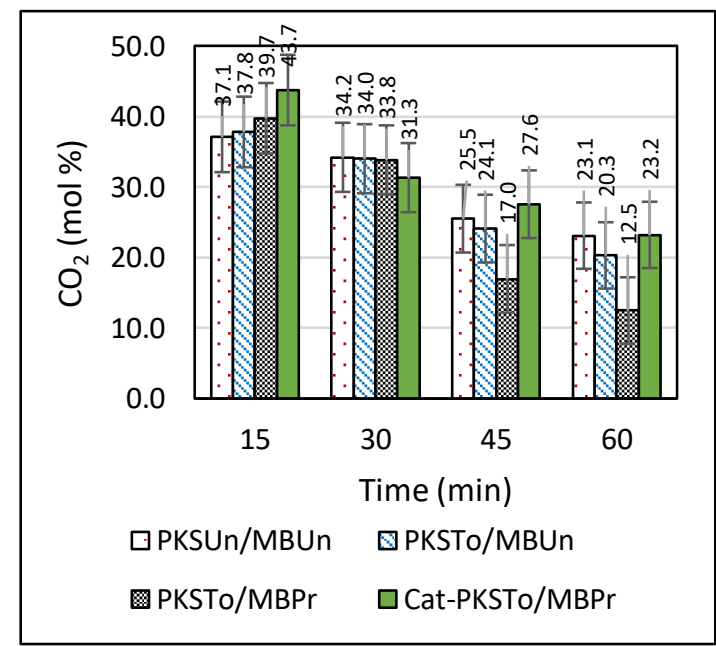

(c) $\mathrm{CO}_{2}$

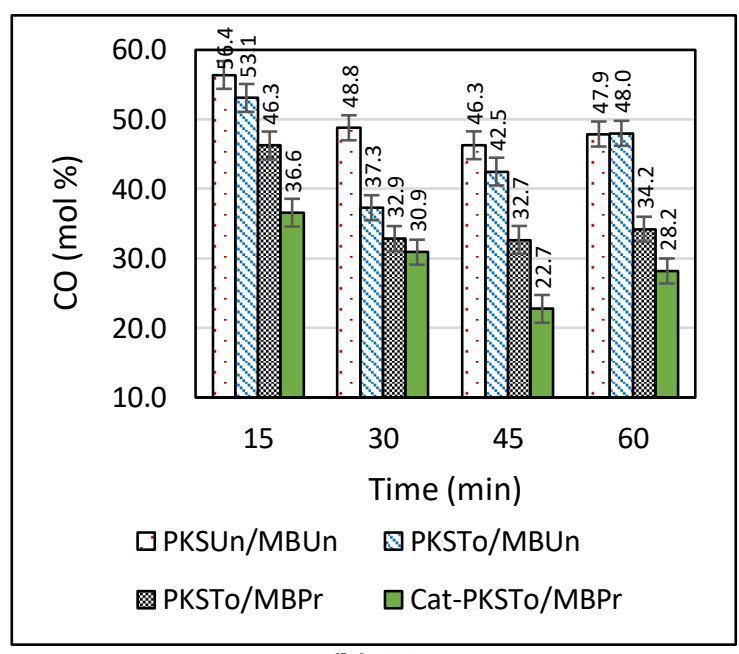

(b) $\mathrm{CO}$

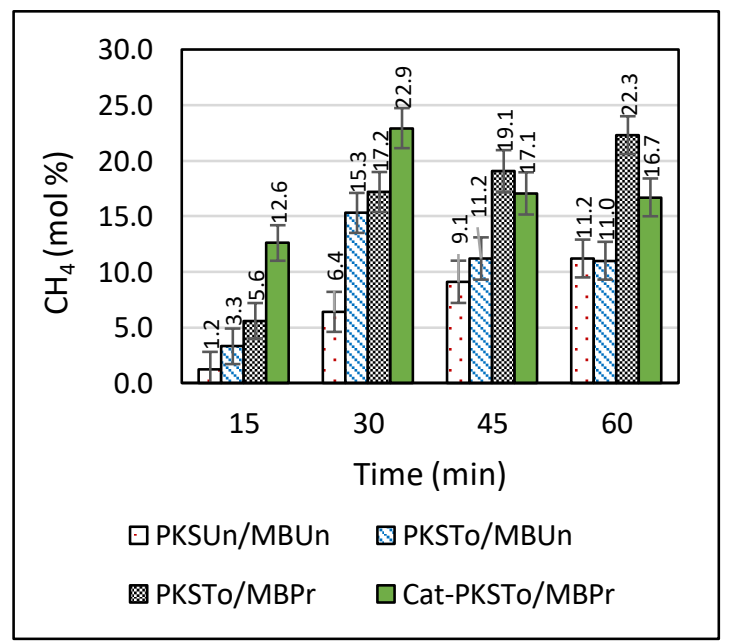

(d) $\mathrm{CH}_{4}$

Figure 3 Effect of co-gasification of $\mathrm{PKS}_{\mathrm{Un}} / \mathrm{MB}_{\mathrm{Un}}, \mathrm{PKS}_{\mathrm{To}} / \mathrm{MB}_{\mathrm{Un}}, \mathrm{PKS}_{\mathrm{To}} / \mathrm{MB}_{\mathrm{Pr}}$, and Cat-PKS $\mathrm{PTo}_{\mathrm{To}} / \mathrm{MB}_{\mathrm{Pr}}$ on gases composition 
Based on Figure 3, $\mathrm{H}_{2}$ and $\mathrm{CH}_{4}$ composition for $\mathrm{PKS}_{U n} / \mathrm{MB}_{U n}, \mathrm{PKS}_{\mathrm{To}} / \mathrm{MB}_{U n}$, and $\mathrm{PKS}_{\mathrm{To}} / \mathrm{MB}_{\mathrm{Pr}}$ increase with increasing reaction time due to water gas-reaction (Equation 3), methanation reaction (Equation 5) and steam reforming reaction (Equation 6). The composition of $\mathrm{CO}$ and $\mathrm{CO}_{2}$ decreases with increasing reaction time due to water-gas shift reaction (Equation 4) and Bourdard reaction (Equation 7), which occurs simultaneously during co-gasification. Generally, for the $\mathrm{PKS}_{\mathrm{Un}} / \mathrm{MB}_{\mathrm{Un}}$, most atomic hydrogen is transformed into $\mathrm{H}_{2} \mathrm{O}$, so the concentration of $\mathrm{H}_{2}$ is very low (Chen et al., 2013). When the $\mathrm{PKS}_{\mathrm{To}} / \mathrm{MB}_{\mathrm{Pr}}$ is gasified, the $\mathrm{H}_{2}$ composition rises significantly. These results clearly indicate that the pretreatment on both PKS and MB coal can facilitate $\mathrm{H}_{2}$ production during co-gasification.

\section{Conclusions}

Co-gasification of PKS and MB coal was done in a fixed bed reactor. The pretreatment of a blend of both samples produced a higher gas yield with lower tar and char yield than the untreated blend of both samples. The $\mathrm{PKS}_{\mathrm{To}} / \mathrm{MB}_{\mathrm{Pr}}$ produced a higher $\mathrm{H}_{2}$ composition of $31.3 \%$, which was more than $\mathrm{PKS}_{U n} / \mathrm{MB}_{U n}$ sample of $19.1 \%$ at 45 min reaction time. The Cat- $\mathrm{PKS}_{\mathrm{To}} / \mathrm{MB}_{\mathrm{Pr}}$ showed a minor increase on $\mathrm{H}_{2}$ composition of $32.6 \%$, which is more than $\mathrm{PKS}_{\mathrm{To}} / \mathrm{MB}_{\mathrm{Pr}}$ of $31.3 \%$ at 45 min reaction time. The lowest $\mathrm{CO}_{2}$ composition at $12.5 \%$ was produced by $\mathrm{PKS}_{\mathrm{To}} / \mathrm{MB}_{\mathrm{Pr}}$ compared with $\mathrm{PKS}_{\mathrm{Un}} / \mathrm{MB}_{\mathrm{Un}}$ at $20.3 \%$ in a reaction time of $60 \mathrm{~min}$. Thus, the $\mathrm{PKS}_{\mathrm{To}} / \mathrm{MB}_{\mathrm{Pr}}$, which had been enriched in their properties, improved the cogasification performance in terms of product yield and gas composition.

\section{Acknowledgements}

This research project is funded by the Ministry of Higher Education, Malaysia, under the Fundamental Research Grant Scheme (FRGS), FRGS/1/2017/TK10/UITM/02/11.

\section{References}

Ahmad, R., Hamidin, N., Ali, U.F.M., Abidin, C.Z.A., 2014. Characterization of Bio-oil from Palm Kernel Shell Pyrolysis. Journal of Mechanical Engineering and Sciences, Volume 7(1), pp. 1134-1140

Ahmad, R., Ishak, M.A.M., Kasim, N.N., Ismail, K., 2018. Optimization of Co-gasification Process Parameters of Pretreated Palm Kernel Shell and Pretreated Malaysian Low Rank Coal using Response Surface Methodology. In: AIP Conference Proceedings, Volume 2013(1)

Ahmad, R., Ishak, M.A.M., Kasim, N.N., Ismail, K., 2019. Properties and Thermal Analysis of Upgraded Palm Kernel Shell and Mukah Balingian Coal. Energy, Volume 167 pp. 538547

Berrueco, C., Montané, D., Matas Güell, B., del Alamo, G., 2014. Effect of Temperature and Dolomite on Tar Formation during Gasification of Torrefied Biomass in a Pressurized Fluidized Bed. Energy, Volume 66, pp. 849-859

Brar, J.S., Singh, K., Wang, J., Kumar, S., 2012. Cogasification of Coal and Biomass: A Review. International Journal of Forestry Research, Volume 2012, pp. 1-10

Chen, W.H., Chen, C.J., Hung, C.I., Shen, C.H., Hsu, H.W., 2013. A Comparison of Gasification Phenomena among Raw Biomass, Torrefied Biomass and Coal in an Entrained-flow Reactor. Applied Energy, Volume 112, pp. 421-430

Chen, W.H., Peng, J., Bi, X.T., 2015. A State-of-the-art Review of Biomass Torrefaction, Densification and Applications. Renewable and Sustainable Energy Reviews, Volume 44, pp. 847-866

Dudyński, M., van Dyk, J.C., Kwiatkowski, K., Sosnowska, M., 2015. Biomass Gasification: 
Influence of Torrefaction on Syngas Production and Tar Formation. Fuel Processing Technology, Volume 131, pp. 203-212

Heidenreich, S., Foscolo, P.U., 2015. New Concepts in Biomass Gasification. Progress in Energy and Combustion Science, Volume 46, pp. 72-95

Howaniec, N., Smoliński, A., 2013. Steam Co-gasification of Coal and Biomass - Synergy in Reactivity of Fuel Blends Chars. International Journal of Hydrogen Energy, Volume 38, pp. 16152-16160

Howaniec, N., Smoliński, A., Stańczyk, K., Pichlak, M., 2011. Steam Co-gasification of Coal and Biomass Derived Chars with Synergy Effect as an Innovative Way of Hydrogen-rich Gas Production. International Journal of Hydrogen Energy, Volume 36(22), pp. 1445514463

Kasim, N.N., Mohamed, A.R., Ishak, M.A.M., Ahmad, R., Nawawi, W.I., Ali, S.N., Ismail, K., 2019. The Effect of Demineralization and Torrefaction Consequential Pre-treatment on Energy Characteristic of Palm Empty Fruit Bunches. Journal of Thermal Analysis and Calorimetry. Volume 138, pp. 343-350

Krerkkaiwan, S., Fushimi, C., Tsutsumi, A., Kuchonthara, P., 2013. Synergetic Effect during Co-pyrolysis/Gasification of Biomass and Sub-bituminous Coal. Fuel Processing Technology, Volume 115, pp. 11-18

Kuo, P., Wu, W., Chen, W., 2014. Gasification Performances of Raw and Torrefied Biomass in a Downdraft Fixed Bed Gasifier using Thermodynamic Analysis. Fuel, Volume 117(Part B), pp. 1231-1241

Mallick, D., Mahanta, P., Moholkar, V.S., 2017. Co-gasification of Coal and Biomass Blends: Chemistry and Engineering. Fuel, Volume 204, pp. 106-128

Moghadam, R.A., Yusup, S., Uemura, Y., Chin, B.I.F., Lam, H.L., Al Shoaibi, A., 2014. Syngas Production from Palm Kernel Shell and Polyethylene Waste Blend in Fluidized Bed Catalytic Steam Co-gasification Process. Energy, Volume 75, pp. 40-44

Mohr, S.H., Wang, J., Ellem, G., Ward, J., Giurco, D., 2015. Projection of World Fossil Fuels by Country. Fuel, Volume 141, pp. 120-135

Naqvi, M., Yan, J., Danish, M., Farooq, U., Lu, S., 2016. An Experimental Study on Hydrogen Enriched Gas with Reduced Tar Formation using Pre-treated Olivine in Dual Bed Steam Gasification of Mixed Biomass Compost. International Journal of Hydrogen Energy, Volume 41(25), pp. 10608-10618

Nhuchhen, D., Basu, P., Acharya, B., 2014. A Comprehensive Review on Biomass Torrefaction. International Journal of Renewable Energy \& Biofuels, Volume 2014, pp. $1-56$

Parthasarathy, P., Narayanan, K.S., 2014. Hydrogen Production from Steam Gasification of Biomass: Influence of Process Parameters on Hydrogen Yield-A Review. Renewable Energy, Volume 66, pp. 570-579

Rao, Z., Zhao, Y., Huang, C., Duan, C., He, J., 2015. Recent Developments in Drying and Dewatering for Low Rank Coals. Progress in Energy and Combustion Science, Volume 46, pp. $1-11$

Sulaiman, S.A., Atnaw, S.M., Moni, M.N.Z., 2012. Experimental Study on Temperature Profile of Fixed-bed Gasification of Oil-palm Fronds. International Journal of Technology, Volume 3(1), pp. 35-44

Strege, J., Swanson, M., Folkedahl, B., Stanislowski, J., Laumb, J., 2011. Fischer-Tropsch Catalyst Testing in a Continuous Bench-scale Coal Gasification System. Fuel Processing Technology, Volume 92(4), pp. 757-763

Taba, L.E., Irfan, M.F., Wan Daud, W.A.M., Chakrabarti, M.H., 2012. The Effect of Temperature on Various Parameters in Coal, Biomass and Co-gasification: A review. Renewable and 
Sustainable Energy Reviews, Volume 16(8), pp. 5584-5596

Valdés, C.F., Chejne, F., Marrugo, G., Macias, R.J., Gómez, C.A., Montoya, J.I., Arenas, E., 2016. Co-gasification of Sub-bituminous Coal with Palm Kernel Shell in Fluidized Bed Coupled to a Ceramic Industry Process. Applied Thermal Engineering, Volume 107, pp. 1201-1209

Winaya, N.S., Hartati, R.S., Lokantara, P., Subawa, G., Putrawan, M.A., 2015. Fluidized Bed Co-gasification of Coal and Solid Waste Fuels in an Air Gasifying Agent. International Journal of Technology, Volume 6(6), pp. 931-937

Xia, W., Xie, G., Peng, Y., 2015. Recent Advances in Beneficiation for Low Rank Coals, Powder Technology, Volume 277, pp. 206-221

Yuan, S., Dai, Z., Zhou, Z., Chen, X., Yu, G., Wang, F., 2012. Rapid Co-pyrolysis of Rice Straw and a Bituminous Coal in a High-frequency Furnace and Gasification of the Residual Char. Bioresource Technology, Volume 109, pp. 188-197

Yuliansyah, A.T., Putri, C.O., Clarasinta, B.D. Nonaka, M., 2019. TGA Investigation of $\mathrm{CO}_{2}$ Gasification of Hydrothermally Treated Biomass (Corn Cob-Coconut Shell Mixture). International Journal of Technology, Volume 10(6), pp. 1166-1173 